\title{
The Determinants of Capital Structure: Empirical evidence from Thai Banks
}

\author{
David E. Allen, Napaporn Nilapornkul*, Robert John Powell \\ School of Accounting, Finance and Economics, Edith Cowan University, Western Australia \\ *nnilapor@ecu.edu.au
}

\begin{abstract}
The aim of this study is to examine the determinants of the capital structure of Thai banks. The data spans a ten year period from 1999 - 2008. The differentiation point of this study is that, whereas most studies on capital structure focus predominantly on internal bank variables, this study, in addition to internal variables includes market-based risk variables. A range of market-based default and value at risk variables were considered which were then narrowed down to improve the model. Fixed effects panel data analysis is employed, with both market and book leverage used as dependent variables. The Thai bank study is benchmarked to Japanese and Malaysian banks. The study found that the significance of the market-based variables is greater for market leverage than for book leverage. The results can assist regulators and banks in understanding the impact of different market and internal variables on capital.
\end{abstract}

Keyword: Capital structure, Distance to default, Conditional value at risk, Panel data analysis

\section{Introduction}

The Asian Financial Crisis (AFC) originated in Thailand in the middle of 1997. A major cause of the AFC was the Thai financial liberalization of the 1980s; such as the relaxing of interest rate ceilings, leading to an increase in bank transactions, especially international loans. Concurrently, the Thai government floated the Baht on July 2, 1997, and it fell approximately $20 \%$ against the US\$ on that day, with a further 36.7\% drop on September 1998 (Karunatilleka, 1999). Then, the Thai banking sector was handicapped by non-performing loans (NPLs), which were approximately 15\% of assets in 1997 (Beeson \& Rosser, 1998). These phenomena led to a severe recession in Thailand, with GDP growth rate at $-1.4 \%$ in 1997 and 10.5\% in 1998 (World Bank, 2011).Thereafter, the currency devaluation spread to other Asian countries; such as Malaysia, South Korea and Indonesia. To rescue the Thai financial system, financial contribution came from many sources such as the World Bank. Major funding of \$US 3.9 billion came from the International Monetary Fund (IMF). However, the Minister of Finance (MOF) and the Bank of Thailand (BOT) had to develop the Financial Sector Master Plan (FSMP) to reform the financial sector under the IMF's policy. This included a restructure of the Thai banking sector by selling banks to, or merging them with, the private sector to strengthen financial institutions and transparency. The next crisis, the Global Financial Crisis (GFC) commenced in the United States in late 2007. Many studies stated that a major causes of the GFC was lax regulatory controls by allowing poor credit standards, coupled with excessive leverage and maturity transformation by banks in the United States (Blankenburg \& Palma, 2009). This crisis finally expanded into European and Asian countries.

Due to global default risk and a huge restructure of the Thai banking sector since the AFC, the current research question is what are the determinants influencing the Thai bank capital structure after the AFC. Importantly, a sub research question is the extent to which market based explanatory variables impact on leverage. This includes distance to default $(D D)$ and parametric conditional value at risk (PCVaR), which currently no available study specifically applies to Thai bank capital structure. Additionally, under the Basel Accord, banks use market-based assessment tools to assess credit and market risk of banks' customers in order for banks to calculate appropriate bank capital requirements, which might be impact on bank capital structure. . To benchmark this study, the Thai banking sector is compared with one Asian developing country (Malaysia) and with one Asian advanced country (Japan). Specifically, Malaysia faced a financial disaster experience similar to Thailand such as a large of depreciation of the ringgit and a massive increase in non-performing loans. Thus, this comparison study will assist in understanding differences in capital determinants between developing and developed Asian financial systems. The next section undertakes a literature review, including capital structure theory, previous studies on capital determinants, and background on the banking sector. Section 3 contains data and research methodology. Then, findings and discussions are provided in Section 4, followed by conclusions and recommendations in Section 5. 


\section{Literature Review}

Theory and empirical study: Classical capital structure theory was developed by Modigliani and Miller (MM), which subsequently developed into many modern capital structure theories. In this study, three key theories are described: the Trade-off theory, Pecking order theory and Agency cost theory. The first, Trade-off theory states that optimal capital structure is obtained by considering a trade-off between the benefit and downside of debt financing to meet an appropriate debt ratio, which maximizes its firm value (Haas \& Peeters, 2006). Next, Pecking order theory indicates that firms prefer to generate internal funds than external funds. Thus, retained earnings will be the first source of funds followed by debt and equity respectively. The last, Agency cost theory deals with conflict of interest between two parties. For example, conflict between bondholders and management occurs when management prefer to invest in a risky project to maximize shareholder's wealth, reflecting the transfer of investment risk from shareholders to debt holders. This agency problem can be called the "asset substitution problem" (Harris \& Raviv, 1991). Numerous empirical studies on determinants of capital structure have been published over the years. A variety of dependent variables have been used such as book leverage (the ratio of total debt to book value of total assets), shown in the studies of Ali, Akhtar \& Sadaqat(2011) for Pakistan, and Caglayan and Sak(2010) for Turkish banks. The next example is market leverage (the ratio of total debt to market value of total assets), found in the studies of Juca, Sousa and Fishlow(2012) for North Amercian banks. However, both leverages were also employed in Gropp and Heider (2010) for the U.S and European banks and in Monica and Brown (2010) for banks in the 10 developing countries.

Similarly, many explanatory variables such as size and profitability have been popular among researchers. However, there is still controversy regarding the determinants influencing capital structure due to different outcomes. For example, bank size has been found to have a positive relationship to leverage for Pakistan banks (Ali et al., 2011), but a contradictory sign was found in North American banks (Juca, Sousa, \& Fishlow, 2012). In terms of market-based risk, no paper studies the influence of the market-based variables used in this study on Thai bank capital structure. Most other papers use marketbased risk assessment in different ways to this paper. For example, Chan-Lau, Jobert and Kong (2004) estimated distance to default (DD) for banks in emerging market countries and tested their ability to forecast banking crises. Allen, Powell and Singh (2011) used DD and Probability of default (PD) coupled with quantile regression to estimate capital buffer requirements for Japanese banks.

Banking sector: This section provides background, firstly on the Thai banking sector, and then on the Japanese and Malaysian banking sectors. The Bank of Thailand (BOT) is the central bank of Thailand. Prior to the AFC, there were 178 financial institutions under the supervision of the BOT (Bank of Thailand, 1997). However, after a huge change in the financial landscape resulting from the Thai government's policy, the structure of financial institutions has been substantially changed with a large reduction in the number of financial entities. In 2010, there are 38 financial institutions under BOT supervision, including 14 Thai banks, 15 foreign bank branches, 2 retail banks, 1 subsidiary bank, 3 finance companies, and 3 credit fancier firms. In Japan, the Financial Service Agency (FSA) acts as a regulatory authority of financial institutions. The Bank of Japan (BOJ) also plays a role, by conducting examinations in order to maintain the soundness of the financial system. Since 1990, the Japanese financial institutions system has been reformed because of suffering from the asset price bubble bursting. The lack of decisive, extensive strategy to address the banking sector problem at an early stage allowed a system crisis to emerge in 1997 - 1998 (Kawai, 2005). After these banking reforms, the Japanese banking system consists mainly of three big holding or Mega banking groups: Mitsubishi UFJ Financial Group, Sumitomo Mitsui Financial Group and Mizuho Financial Group. Additionally, there are currently many smaller categories of banks in Japan: 6 city banks, 64 regional banks, 44 second association of regional banks, 61 foreign banks and 32 other banks (Japanese Banker's Association, 2011). For Malaysia, Bank Negara Malaysia is the central bank, which launched a Financial Sector Master plan for finance sector recovery since the AFC. The licensed banks registered in Malaysia, consist of 27 commercial banks, 16 Islamic banks, 5 international Islamic banks, 15 investment banks, and 2 other financial institutions (Bank Negara Malaysia, 2011).

\section{Methodology}

Data: This study uses panel data, also known as cross sectional time series data. Only publicly traded banks were used in order to obtain market data for calculating the market risk metrics. Data was collected from Thomson Reuters DataStream and individual banks' annual reports online. The fiscal years from 1999 to 2008 were used. In addition, data is on an annual basis, except for stock price index data, which is obtained daily for computing market-based risk variables. The collected data are provided, firstly 
on Thai banks, and then Japanese and Malaysian banks as below. For Thai banks, data were obtained from the bank list of the Bank of Thailand (BOT) and the Stock Exchange of Thailand (SET). In 2010, 10 out of 14 Thai banks are included, representing 81.04\% of total Thai bank assets (\$389 US bn). Similarly, Japanese bank data were obtained from the Japanese Bankers Association (JBA) and Japanese stock exchanges such as the Tokyo Stock Exchange, Nagoya Stock Exchange and Fukuoka Stock Exchange. In 2010, 70banks are included, with total assets representing $88.64 \%$ of the total assets of the Japanese banking sector (\$10 US trillion). Malaysian banks were obtained from the list of licensed banking institutions, provided by the Bank Negara Malaysia (Bank Negara Malaysia, 2011) and from listings on the Kuala Lumpur Stock Exchange. Eight Malaysian banks were included; their total assets representing $88.61 \%$ of the total assets of the Malaysian banking sector (\$50USbn) in 2010.

Market-based Variables: Initially seven market-based variables were considered: distance to default, conditional distance to default, probability of default, parametric and historical of value at risk, and parametric and historical of conditional value at risk. The first three of these variables measure credit risk based on fluctuations in asset values and the others measure share price volatility. To avoid collinear variables, they were separately analyzed for selecting only one credit risk variable and one share price variable, , and finally distance to default $(D D)$ and parametric conditional value at risk $(P C V a R)$ were selected because of providing a slightly better fit in term of $\mathrm{R}^{2}$. Their methodologies are discussed below.

DD methodology: Distance to default $(D D)$ is a default risk indicator, measured as the number of standard deviations away from the default point. $D D$ is calculated by using the Merton (1974) structuralform model, whereby a default will occur when the market value of a firm's assets is lower than its liabilities, which is a modification of the option pricing model of Black and Scholes (Black \& Scholes, 1973). Moody's KMV model (Crosbie \& Bohn, 2003) was developed from the Merton model, and is widely used by banks to measure DD. Following the KMV model, this study defines debt as short-term liabilities (one year and under) plus a half of the book value of all long-term debt. Using equity returns and the relationship between equity and assets, this study estimate an initial assets return. Daily log return is calculated and new asset values are estimated for every day. Following KMV, this is repeated until asset returns converge. The standard deviation of these asset returns is used in the calculation of $D D$ as per equation below:

$\mathrm{DD}$

$\frac{\ln (V / F)+\left(\mu-0.5 \sigma_{v}^{2}\right) T}{\sigma_{v} \sqrt{T}}$

Where $\mathrm{V}=$ the market value of firm, $\mathrm{F}=$ face value of firm's debt, $\mu=$ an estimate of the annual return (drift) of the firm's assets, $\sigma_{v}=$ the standard deviation of the asset returns, $\mathrm{T}=1$ year.

PCVaR calculation: Conditional Value at Risk is the conditional expected loss under the condition it exceeds VaR, known as Tail VaR(Rockafellar \& Uryasev, 2000). Prior to calculating PCVaR, Value at Risk (VaR) is calculated by following Risk Metrics (Morgan \& Reuters, 1996), which is a popular VaR method. To obtain $V a R$, normal curve distribution is assumed. In the context of risk measurement, daily equity returns are calculated by using the logarithm of the ratio between current price $\left(\mathrm{P}_{\mathrm{t}}\right)$ and the previous price $\left(\mathrm{P}_{\mathrm{t}-1}\right)$, as below.

$$
\mathrm{r}_{\mathrm{t}} \quad=\ln \left(\frac{P_{t}}{P_{t-1}}\right)
$$

Although $\operatorname{VaR}$ is a popular risk assessment tool, there are some weaknesses. A primary shortfall of $V a R$ is that it does not measure any losses beyond VaR, but PCVaRdoes.PCVaR uses the same methodology as $V a R$, but the average of the returns beyond $V a R$ is used. For instance, $V a R_{\mathrm{x}}$ at $95 \%$ confidence level = $1.645\left(\sigma_{\mathrm{x}}\right)$. Thus, PCVaR represents the average of the worst $5 \%$ of asset returns (Powell, 2007).

Variable measurement: Two dependent variables are used: the market and book leverage, and their details are presented in Table 1.

Table 1: The mnemonic and definition equation of dependent variables

\begin{tabular}{|c|c|c|}
\hline Variables & Mnemonic & Definition equation \\
\hline 1. Market leverage & $M k l$ & $\begin{array}{l}\text { Mkl = } 1 \text { - (Market value of equity/Market value of total assets) } \\
\text { Market value of total assets = Market value of equity }+ \text { Total } \\
\text { liabilities }\end{array}$ \\
\hline 2. Book leverage & $B k l$ & Bkl = 1- (Total shareholder's equity/Total assets) \\
\hline
\end{tabular}


Explanatory variables were classified into 3 main groups: 1) standard capital variables, 2) internal risk variables and 3) market-based risk variables. A macroeconomic variable is also included for countryspecification. The country dummy variables are also provided. The details of the explanatory variables are presented in Table 2.

Table 2: The mnemonic, definition and expected sign of explanatory variables

\begin{tabular}{|c|c|c|c|}
\hline Variables & $\begin{array}{l}\text { Mnemo } \\
\text { nic }\end{array}$ & Definition equation & $\begin{array}{l}\text { expected } \\
\text { sign }\end{array}$ \\
\hline \multicolumn{4}{|c|}{ Standard capital structure Variables $\left(S c_{i}\right)$} \\
\hline 1. Bank size & Bze & Bze $=\ln ($ Total assets $)$ & + \\
\hline 2. Growth opportunity & $M t b$ & Mtb = Market value to book value of total assets & - \\
\hline 3. Profitability & $R O A$ & $\begin{array}{l}\text { ROA = Earnings before interest and taxes/Total } \\
\text { assets }\end{array}$ & - \\
\hline \multicolumn{4}{|l|}{ Internal risk Variables $\left(I r_{i}\right)$} \\
\hline 1. Loan ratio & $\operatorname{Lr}$ & Lr = Loans-net/Deposits-total & - \\
\hline 2. Non-performing loan & $\mathrm{Npl}$ & $\mathrm{Npl}=$ Non-performing loan/Total loans & - \\
\hline 3. Risk-weighted asset & Rws & Rws $=$ Risk-weighted assets $/$ Total assets & - \\
\hline \multicolumn{4}{|c|}{ Market-based risk Variables $\left(M k r_{i}\right)$} \\
\hline 1. Distance to default & $D D$ & $\mathrm{DD}=\frac{\ln (V / F)+\left(\mu-0.5 \sigma_{v}^{2}\right) T}{\sigma_{v} \sqrt{T}}$ & + \\
\hline $\begin{array}{l}\text { 2. Conditional value at } \\
\text { risk }\end{array}$ & PCVaR & The average returns beyond $V a R$ & - \\
\hline \multicolumn{4}{|c|}{ Macroeconomics Variable $\left(M c_{i}\right)$} \\
\hline $\begin{array}{l}\text { 1. GDP growth rate } \\
\text { Dummy Variables }\end{array}$ & $G p r$ & The average of annual real GDP growth rate & - \\
\hline 1. Thailand & $\mathrm{DmT}$ & Dummy Variable values 1 for Thailand, 0 otherwise & \\
\hline 2. Japan & $\mathrm{DmJ}$ & Dummy Variable values 1 for Japan, 0 otherwise & \\
\hline 3. Malaysia & $\mathrm{DmM}$ & Dummy Variable values 1 for Malaysia, 0 otherwise & \\
\hline
\end{tabular}

Empirical Model: Prior to running regression models, correlation and variance inflation factor (VIF) factors were calculated to detect multicollinearity. Collinear variables will be dropped from the models. In this study, panel data regression was employed, by considering both fixed effects (FE) and random effects (RE) models. FE model takes account of the heterogeneity effect. RE models, assume a random variable uncorrelated with independent variables. To select the appropriate model between FE and RE, the Hausman (HS) test was used. The null hypothesis of the HS test is that there are not considerably different between the FE and RE. As a result, if the null hypothesis is rejected, the RE is rejected (Gujarati, 2011). In this study, there are two reasons for applying a one year lag to the explanatory variables 1) to account for possible time-lagged effects and 2), to allow comparison to other studies which used one year lags, including the U.S and European banks examined by Gropp and Heider (2010) and the banks in developing countries examined by Monica and Brown (2010). The research process is discussed below. First, this study examines the explanatory power of market-based risk variable group. The first model (includes all variables) is performed as a baseline model. Then, the market-based risk variable group is dropped while the other groups are remaining (Model 2). Then the contribution to adjusted $\mathrm{R}^{2}$ of market-based variable group is calculated.

$Y_{i, t}=\beta_{0}+\beta_{1}$ Bze $_{i, t-1}+\beta_{2} M t b_{i, t-1}+\beta_{3} R O A_{i, t-1}+\beta_{4} L r_{i, t-1}+\beta_{5} N p l_{i, t-1}+\beta_{6} R w s_{i, t-1}+\beta_{7} D D_{i, t-1}+\beta_{8} P C V a R$ i,t-1 $\beta_{9} G p r_{i, t}+C_{i}+C_{t}+\varepsilon_{i, t}$ (1)

$Y_{i, t}=\beta_{0}+\beta_{1} B_{z e_{i, t-1}}+\beta_{2} M t b_{i, t-1}+\beta_{3} R O A_{i, t-1}+\beta_{4} L r_{i, t-1}+\beta_{5} N p l_{i, t-1}+\beta_{6} R w s_{i, t-1}+\beta_{7} G p r_{i, t}+C_{i}+C_{t}+\varepsilon_{i, t}$

Next, to examine the influence of each variable on bank leverage, Model 1 (including all variables) is reemployed in this stage.

Lastly, a one-year lag of leverage is used as an explanatory variable because leverage might be affected by previous years as shown in Model (3)

$Y_{i, t}=\beta_{0} Y_{i, t-1}+\beta_{1}+\beta_{2} \mathrm{Bze}_{i, t-1}+\beta_{3} M t b_{i, t-1}+\beta_{4} R O A_{i, t-1}+\beta_{5} L_{i, t-1}+\beta_{6} N p l_{i, t-1}+\beta_{7} R w s_{i, t-1}+\beta_{8} D D_{i, t-1}+\beta_{9} P C V a R_{i, t-1}+\beta_{10} G p r_{i, t}+C_{i}+$ $C_{t}+\varepsilon_{i, t}(3)$

Where $Y_{i, t}$ depicts market or book leverage. $i$ and $t$ represent bank and year respectively. $\varepsilon_{i, t}$ is the random error term. 
For individual country analysis, country dummy variables are used, by multiplying each explanatory variably by country dummy variable, for example, for Thai banks in Model (2)

$Y_{i, t}=\beta_{0}+\beta_{1} B z e_{i, t-1} * D m T+\beta_{2} M t b_{i, t-1} * D m T+\beta_{3} R O A_{i, t-1} * D m T+\beta_{4} L r_{i, t-1} * D m T+\beta_{5} N p l_{i, t-1} * D m T+\beta_{6} R w s_{i, t-1} * D m t+\beta_{7} G p r$ ${ }_{I, t-1, t,{ }^{*}}^{*} D m T+C_{i}+C_{t}+\varepsilon_{i, t}$

Where: DmT is the country Dummy variable for Thailand, which is changed to DmJ for Japan and DmM for Malaysian banks.

\section{Results}

Descriptive statistics: The descriptive statistics of variables of sample countries are presented in Table 3 below.

Table 3: Descriptive statistics of variables

\begin{tabular}{|c|c|c|c|c|c|c|}
\hline Variable & Country & Mean & Median & Max & Min & Std. Dev. \\
\hline \multicolumn{7}{|c|}{ Dependent Variable: } \\
\hline \multirow[t]{3}{*}{ Mkl } & Japan & 0.954 & 0.957 & 0.992 & 0.870 & 0.017 \\
\hline & Malaysia & 0.886 & 0.890 & 0.968 & 0.735 & 0.052 \\
\hline & Thailand & 0.894 & 0.908 & 0.985 & 0.652 & 0.071 \\
\hline \multirow[t]{3}{*}{$\mathrm{Bkl}$} & Japan & 0.951 & 0.951 & 0.998 & 0.912 & 0.013 \\
\hline & Malaysia & 0.923 & 0.924 & 0.959 & 0.865 & 0.018 \\
\hline & Thailand & 0.913 & 0.924 & 1.105 & 0.699 & 0.068 \\
\hline \multicolumn{7}{|c|}{ Explanatory Variable: } \\
\hline \multicolumn{7}{|c|}{ Standard capital structure Variable $\left(S c_{i}\right)$ : } \\
\hline \multirow[t]{3}{*}{ Bze } & Japan & 17.047 & 16.923 & 21.430 & 14.852 & 1.016 \\
\hline & Malaysia & 16.684 & 16.610 & 18.293 & 15.224 & 0.734 \\
\hline & Thailand & 16.050 & 16.454 & 17.691 & $\begin{array}{c}13.621 \\
-\end{array}$ & 1.163 \\
\hline \multirow[t]{3}{*}{ Mtb } & Japan & 0.924 & 0.900 & 7.530 & 19.870 & 1.382 \\
\hline & Malaysia & 1.459 & 1.295 & 3.470 & 0.440 & 0.644 \\
\hline & Thailand & 0.856 & 1.255 & 6.35 & -16.81 & 2.824 \\
\hline \multirow[t]{3}{*}{ ROA } & Japan & 0.002 & 0.003 & 0.012 & -0.035 & 0.006 \\
\hline & Malaysia & 0.014 & 0.014 & 0.032 & -0.017 & 0.007 \\
\hline & Thailand & 0.009 & 0.010 & 0.144 & -0.091 & 0.040 \\
\hline \multicolumn{7}{|c|}{ Internal risk Variable $\left(I r_{i}\right):$} \\
\hline \multirow[t]{3}{*}{$\mathrm{Lr}$} & Japan & 0.742 & 0.741 & 0.937 & 0.541 & 0.069 \\
\hline & Malaysia & 1.010 & 0.971 & 1.582 & 0.808 & 0.148 \\
\hline & Thailand & 1.307 & 0.949 & 13.638 & 0.566 & 1.485 \\
\hline \multirow[t]{3}{*}{$\mathrm{Npl}$} & Japan & 0.056 & 0.050 & 0.190 & 0.007 & 0.025 \\
\hline & Malaysia & 0.089 & 0.087 & 0.205 & 0.007 & 0.051 \\
\hline & Thailand & 0.137 & 0.113 & 0.688 & 0.027 & 0.106 \\
\hline \multirow[t]{3}{*}{ Rws } & Japan & 0.554 & 0.542 & 6.734 & 0.242 & 0.245 \\
\hline & Malaysia & 0.680 & 0.675 & 1.335 & 0.298 & 0.187 \\
\hline & Thailand & 0.667 & 0.714 & 1.113 & 0.017 & 0.232 \\
\hline \multicolumn{7}{|c|}{ Market-based Variable $\left(M k r_{i}\right)$ : } \\
\hline \multirow[t]{3}{*}{ DD } & Japan & 3.892 & 3.779 & 15.151 & -0.265 & 1.958 \\
\hline & Malaysia & 3.926 & 4.021 & 9.126 & -1.174 & 2.251 \\
\hline & Thailand & 2.738 & 2.535 & 7.730 & -0.820 & 1.811 \\
\hline \multirow[t]{3}{*}{ Pcv95 } & Japan & 0.966 & 0.699 & 11.569 & 0.225 & 1.179 \\
\hline & Malaysia & 0.782 & 0.716 & 2.436 & 0.359 & 0.350 \\
\hline & Thailand & 1.132 & 1.033 & 5.828 & 0.463 & 0.629 \\
\hline \multicolumn{7}{|c|}{ Macro-economic Variable (Mc) } \\
\hline \multirow[t]{3}{*}{ Gpr } & Japan & 0.013 & 0.019 & 0.029 & -0.012 & 0.013 \\
\hline & Malaysia & 0.056 & 0.058 & 0.089 & 0.005 & 0.020 \\
\hline & Thailand & 0.047 & 0.049 & 0.071 & 0.022 & 0.014 \\
\hline
\end{tabular}

Thailand has a mean value of market leverage (0.894) and book leverage (0.913). These figures are relatively similar to those of Gropp and Heider(2010) for U.S. and European banks, which are 0.873 and 0.926 for market and book leverage respectively. Considering explanatory variables, the ranking of the mean value of bank size is Japan (17.047), Malaysia (16.684) and Thailand (16.050). However, Thailand and Malaysia have relatively high variability (standard deviation) in bank size in accordance with Octavia 
and Brown (2010), who found that there is an extremely large variation of bank size in developing countries. Thailand has a mean value of market to book ratio (0.856), which is the lowest figure among the sample countries. Profitability is quite low in each country in line with Gropp and Heider(2010) who pointed out that banks are a relatively low return industry. For this study, a mean value of $R O A$ is at 0.002 for Japan, 0.014 for Malaysia and 0.009 for Thailand.

Clearly, Thai banks have the highest loan ratio (1.307), followed by the highest non-performing loans $(0.137)$ among country sample. However, Malaysia and Thai banks have similar risk-weighted assets of 0.680 and 0.667 respectively. Japan has relatively low risk because of low non-performing loans and riskweighted assets. Significantly, Thai banks have the highest rank in bank risk because of having lower $D D$ and higher PCVaR. This implies that Thai banks have highest bank risk both in term of internal risk and market and credit risk (market-based risk) among the sample countries. For detecting multicollinearity, Pearson correlation and variance inflation factor (VIF) were calculated. The results show no collinear variables, because no correlation and VIF exceed 0.8 and 10 respectively as are reported in Table 4 .

Table 4: Correlation and variance inflation factors (VIF)

\begin{tabular}{|c|c|c|c|c|c|c|c|c|c|c|c|c|}
\hline VIF & & MkI & BkI & Bze & Mtb & $R O A$ & $L r$ & Npl & Rws & $D D$ & PCVaR & Gpr \\
\hline \multicolumn{13}{|c|}{ Panel A: Japan } \\
\hline & $M k l$ & 1 & & & & & & & & & & \\
\hline & $B k l$ & 0.45 & 1 & & & & & & & & & \\
\hline 1.15 & Bze & -0.02 & -0.14 & 1 & & & & & & & & \\
\hline 1.05 & $M t b$ & 0.08 & -0.12 & -0.04 & 1 & & & & & & & \\
\hline 1.46 & $R O A$ & -0.40 & -0.37 & 0.18 & 0.15 & 1 & & & & & & \\
\hline 1.08 & $L r$ & 0.26 & -0.05 & -0.06 & 0.02 & -0.09 & 1 & & & & & \\
\hline 1.37 & $\mathrm{Npl}$ & 0.31 & 0.19 & -0.35 & 0.00 & -0.42 & 0.12 & 1 & & & & \\
\hline 1.06 & $R w s$ & -0.01 & -0.01 & 0.04 & 0.02 & 0.01 & 0.22 & 0.04 & 1 & & & \\
\hline 1.23 & $D D$ & -0.07 & -0.27 & -0.01 & 0.16 & 0.22 & -0.11 & -0.05 & -0.05 & 1 & & \\
\hline 1.05 & PCVaR & 0.12 & 0.15 & -0.05 & -0.04 & -0.15 & 0.06 & 0.08 & 0.00 & -0.17 & 1 & \\
\hline 1.30 & $G p r$ & -0.23 & -0.28 & -0.01 & 0.06 & 0.35 & -0.06 & -0.03 & -0.04 & 0.38 & -0.15 & 1 \\
\hline \multicolumn{13}{|c|}{ Panel B: Malaysia } \\
\hline & $M k l$ & 1 & & & & & & & & & & \\
\hline & $B k l$ & 0.38 & 1 & & & & & & & & & \\
\hline 2.35 & Bze & 0.02 & -0.50 & 1 & & & & & & & & \\
\hline 1.96 & $M t b$ & 0.12 & -0.61 & 0.45 & 1 & & & & & & & \\
\hline 1.42 & $R O A$ & -0.27 & -0.55 & 0.34 & 0.29 & 1 & & & & & & \\
\hline 1.32 & $L r$ & 0.17 & 0.17 & -0.13 & 0.01 & 0.08 & 1 & & & & & \\
\hline 1.85 & $\mathrm{Npl}$ & 0.24 & 0.50 & -0.50 & -0.15 & -0.40 & 0.16 & 1 & & & & \\
\hline 1.37 & $R w s$ & -0.22 & -0.38 & 0.28 & 0.22 & 0.11 & 0.22 & 0.17 & 1 & & & \\
\hline 2.20 & $D D$ & -0.05 & -0.65 & 0.36 & 0.46 & 0.36 & -0.09 & -0.36 & 0.10 & 1 & & \\
\hline 2.20 & PCVaR & 0.26 & 0.30 & -0.38 & 0.04 & -0.07 & 0.39 & 0.27 & -0.03 & -0.48 & 1 & \\
\hline 1.06 & $G p r$ & -0.04 & -0.06 & -0.01 & 0.01 & 0.15 & 0.02 & -0.04 & 0.00 & -0.03 & -0.07 & 1 \\
\hline \multicolumn{13}{|c|}{ Panel C: Thailand } \\
\hline & $M k l$ & 1 & & & & & & & & & & \\
\hline & $B k l$ & 0.74 & 1 & & & & & & & & & \\
\hline 1.48 & Bze & 0.57 & 0.44 & 1 & & & & & & & & \\
\hline 1.03 & $M t b$ & -0.17 & -0.22 & 0.0 & 1 & & & & & & & \\
\hline 2.64 & $R O A$ & -0.49 & -0.32 & -0.32 & 0.03 & 1 & & & & & & \\
\hline 1.67 & $L r$ & -0.39 & -0.40 & -0.39 & 0.05 & 0.01 & 1 & & & & & \\
\hline 1.62 & $\mathrm{Npl}$ & 0.22 & -0.03 & 0.08 & -0.13 & -0.30 & -0.13 & 1 & & & & \\
\hline 1.52 & Rws & -0.35 & -0.22 & -0.11 & -0.01 & 0.44 & 0.14 & 0.03 & 1 & & & \\
\hline 2.05 & $D D$ & -0.13 & -0.26 & 0.08 & 0.06 & 0.27 & 0.07 & -0.10 & 0.11 & 1 & & \\
\hline 1.72 & PCVaR & 0.13 & 0.03 & -0.20 & -0.03 & -0.11 & -0.05 & 0.09 & -0.21 & -0.55 & 1 & \\
\hline 1.56 & $G p r$ & -0.09 & -0.29 & -0.02 & 0.05 & -0.04 & 0.13 & 0.05 & 0.00 & 0.46 & -0.39 & 1 \\
\hline
\end{tabular}

Generally, the majority of the correlations are in accordance with the findings in capital structure literature. In terms of Thai banks, larger banks tend to have lower profits and higher leverage, which is in accordance with Gropp and Heider(2010). Conversely, larger banks in Japan and Malaysia have lower leverage, but more profits. Larger banks in Japan and Malaysia have lower non-performing loans but higher risk-weight assets in contrast to Thai banks. Regarding market-based variable, larger banks in Thai and Malaysia appear to be relatively safe because of higher DD and lower PCVaR. 
Regression results: A fixed effects model is used in this study because the Hausman test significantly rejects the null hypothesis in all regressions. The Wald test shows no zero coefficients for explanatory variables in the models. Additionally, the White-cross section estimator is used to generate estimation of standard errors that are robust to cross-section (contemporaneous) correlation as well as heteroskedasticity among banks (Eviews 7, 2009). This section was divided into three major subsections: examining the contribution to adjusted $\mathrm{R}^{2}$, examining the influence of explanatory variables and examining the impact of one-year lagged of dependent variables. The details of these subsections are reported below:

The explanaory power of market-based variables: Regressions are run and compare the baseline Model (1) with Model (2) for calculating the contribution to adjusted $\mathrm{R}^{2}$, reflecting the explanatory power of market-based variable group. Only adjusted $\mathrm{R}^{2}$ is reported as shown in Table 5 below.

\section{Table 5: Contribution to adjusted $\mathbf{R}^{2}$}

\begin{tabular}{|c|c|c|c|c|c|c|}
\hline \multicolumn{7}{|c|}{$\begin{array}{l}\text { The regression models estimates all bank samples during } 1999-2008 \text {. The FE estimation, employing } \\
\text { bank and time fixed effects is shown below: } \\
Y_{i, t}=\beta_{0}+\beta_{1} B z e_{i, t-1}+\beta_{2} M t b_{i, t-1}+\beta_{3} R O A_{i, t-1}+\beta_{4} L r_{i, t-1}+\beta_{5} N p l_{i, t-1}+\beta_{6} R w s_{i, t-1}+\beta_{7} D D_{i, t-1}+\beta_{8} P C V a R_{i, t-1}+\beta_{9} G p r_{i, t}+C_{i}+C_{t}+ \\
\mathcal{E}_{i, t}\end{array}$} \\
\hline \multicolumn{7}{|c|}{$Y_{i, t}=\beta_{0}+\beta_{1}$ Bze $_{i, t-1}+\beta_{2} M t b_{i, t-1}+\beta_{3} R O A_{i, t-1}+\beta_{4} L r_{i, t-1}+\beta_{5} N p l_{i, t-1}+\beta_{6} R w s_{i, t-1}+\beta_{7} G p r_{i, t}+C_{i}+C_{t}+\varepsilon_{i, t}$} \\
\hline & Thailand & & Japan & & Malaysia & \\
\hline & Market & Book & Market & Book & Market & Book \\
\hline & & levera & & leve & & \\
\hline \multicolumn{7}{|l|}{ Market-based risk } \\
\hline & 0.0032 & 0.0023 & 0.0046 & 0 & 5 & 0.00 \\
\hline
\end{tabular}

The results show clearly that adding market-based variables improves the explanatory power in each country sample. The market-based variable provides adjusted $\mathrm{R}^{2}$ on market leverage higher than book leverage in Japanese and Thai banks.

Examining explanatory variables: Baseline Model (1) (with all explanatory variables) is used to examine the determinants of leverage. The results are presented in Table 6, which shows that, for Thai banks the model provides a similar explanation $\left(R^{2}\right)$ for book leverage $(0.7969)$ and market leverage (0.7908). Profit has a negative relationship with market leverages of Thai banks, but with a contradictory sign for book leverage. Similarly, nonperforming loans are negatively related to market leverage. In contrast, it has a positive relationship with book leverage significance at the $1 \%$ level. Risk-weighted assets have a positive sign for both leverages, but statistical significance at $5 \%$ for book leverage, which support the Basel II capital calculation, which is based on risk-weighted assets. Distance to default and parametric value at risk are negatively related to both leverages, but there is no significance. GDP growth has a negative relationship to market and book leverage, but it has significance at $1 \%$ for market leverage. Regarding cross-country comparison, $\mathrm{R}^{2}$ in each country shows similar results. For Japanese banks, it is clear that market-based variables strongly impact on market leverage. The standard capital structure group variables significantly impact on book leverage at $1 \%$ level, which support Gropp and Heider(2010) for banks in developed countries. Similarly, parametric conditional value at risk is significant at the same level (at 1\%) for book leverage. This implies that for a developed country like Japan, market-based variables strongly impact on market leverage due to fluctuations in the market price of assets and equities; while the effect on book leverage could be because of capital adequacy ratios introduced by the Basel accord. For Malaysian banks, loan ratio and risk-weighted assets has a negative relationship to market leverage at significance of 5\%; while non-performing loans have a positive sign at significance of $1 \%$. Bank size, profitability, non-performing loans, distance to default and parametric conditional value at risk provide significance at $1 \%$ for book leverage. For a developing country such as Malaysia, the Basel accord strongly impacts on book leverage, not on market leverage.

Adding a one-year lag to the dependent Variable: Lastly, a one-year lag is applied to leverage as an explanatory variable. Model 3 (including a one-year lag of dependent variable) is employed and results are shown in Table 7.

The regression models estimates all bank sample (including Thailand, Malaysia and Japan). The FE estimation, employing bank and time fixed effects is shown below: 
Table 6: Examining determinants of bank leverage

\begin{tabular}{|c|c|c|c|c|c|c|c|c|}
\hline \multicolumn{9}{|c|}{$\begin{array}{l}Y_{i, t}=\beta_{0}+\beta_{1} B z e_{i, t-1}+\beta_{2} M t b_{i, t-1}+\beta_{3} R O A_{i, t-1}+\beta_{4} L r_{i, t-1}+\beta_{5} N p l_{i, t-1}+\beta_{6} R w s_{i, t-1}+\beta_{7} D D_{i, t-1}+\beta_{8} P C V a R \\
\varepsilon_{i, t}\end{array}$} \\
\hline & \multicolumn{2}{|c|}{ Aggregated data } & \multicolumn{2}{|c|}{$\begin{array}{l}\text { Japan } \\
\text { Coefficie }\end{array}$} & \multirow{2}{*}{$\begin{array}{l}\text { Malaysia } \\
\text { Coefficient }\end{array}$} & \multirow[b]{2}{*}{$\mathrm{t}$} & \multirow{2}{*}{$\begin{array}{l}\text { Thailand } \\
\text { Coefficient }\end{array}$} & \multirow[b]{2}{*}{$\mathrm{t}$} \\
\hline & Coefficient & $\mathrm{t}$ & nt & $\mathrm{t}$ & & & & \\
\hline \multicolumn{9}{|c|}{ Panel A: Market leverage } \\
\hline $\mathrm{C}$ & $1.042^{* * *}$ & 4.46 & $1.090^{* * *}$ & 7.74 & $0.928 * * *$ & 47.68 & $1.011^{* * *}$ & 17.76 \\
\hline Bze & -0.003 & -0.21 & -0.010 & -1.00 & 0.016 & 1.38 & -0.039 & -1.07 \\
\hline$M t b$ & -0.000 & -0.87 & -0.001 & -1.03 & -0.004 & -0.40 & 0.000 & 0.28 \\
\hline$R O A$ & -0.22 & -1.25 & -0.104 & -1.12 & 0.235 & 0.49 & -0.340 & -0.87 \\
\hline$L r$ & $-0.032^{* * *}$ & -3.04 & -0.005 & -0.10 & $-0.068^{* *}$ & -2.31 & -0.017 & -0.92 \\
\hline $\mathrm{Npl}$ & $-0.078^{* * *}$ & -3.79 & -0.056 & -0.83 & $0.194 * * *$ & 3.16 & -0.099 & -1.37 \\
\hline Rws & -0.000 & -0.15 & 0.001 & 0.70 & $-0.061^{* *}$ & -2.30 & 0.046 & 1.08 \\
\hline$D D$ & $-0.003^{* * *}$ & -3.48 & $-0.002^{* * *}$ & -3.39 & -0.003 & -0.85 & -0.003 & -0.80 \\
\hline PCVaR & $-0.007^{* * *}$ & -2.82 & $-0.004^{* *}$ & -1.97 & -0.001 & -0.06 & -0.012 & -1.30 \\
\hline Gpr & -0.116 & -0.41 & 0.0423 & 1.02 & 0.146 & 0.54 & $-0.86^{* * *}$ & -2.51 \\
\hline $\mathrm{R}^{2}$ & 0.7817 & & 0.7698 & & 0.7762 & & 0.7908 & \\
\hline Adj $R^{2}$ & 0.7503 & & 0.7368 & & 0.7441 & & 0.7608 & \\
\hline$N$ & 838 & & 838 & & 838 & & 838 & \\
\hline F-stats & $24.96^{* * *}$ & & $23.31^{* * *}$ & & $24.17^{* * *}$ & & $26.36^{* * *}$ & \\
\hline \multicolumn{9}{|c|}{ Panel B: Book leverage } \\
\hline $\mathrm{C}$ & $0.862^{* * *}$ & $\begin{array}{c}12.5 \\
5\end{array}$ & $0.774^{* * *}$ & 11.22 & $0.902^{* * *}$ & 93.36 & $0.984^{* * *}$ & 44.35 \\
\hline Bze & 0.005 & 1.31 & $0.015^{* * *}$ & 3.12 & $0.028 * * *$ & 5.32 & $-0.025^{*}$ & -1.87 \\
\hline$M t b$ & -0.001 & -0.77 & $0.001^{* * *}$ & 2.97 & -0.007 & -1.55 & -0.000 & -0.42 \\
\hline$R O A$ & $-0.168^{* * *}$ & -3.04 & $-0.161^{* * *}$ & -4.24 & $-0.811^{* * *}$ & -2.93 & 0.039 & 0.27 \\
\hline$L r$ & -0.007 & -1.47 & $-0.048^{* *}$ & -2.40 & -0.019 & -0.81 & -0.005 & -0.49 \\
\hline $\mathrm{Npl}$ & $0.106^{* * *}$ & 4.18 & 0.050 & 1.42 & $0.220^{* * *}$ & 3.67 & $0.132^{* * *}$ & 3.56 \\
\hline$R w s$ & -0.001 & -0.73 & $-0.001^{*}$ & -1.70 & -0.002 & -0.20 & $0.042^{* *}$ & 1.99 \\
\hline$D D$ & -0.000 & -1.26 & -0.000 & -1.20 & $0.004^{* * *}$ & 2.82 & -0.003 & -1.55 \\
\hline PCVaR & -0.002 & -1.59 & $-0.003^{* * *}$ & -4.20 & $0.015^{* * *}$ & 4.28 & -0.004 & -1.55 \\
\hline$G p r$ & -0.062 & -0.50 & -0.165 & -0.62 & -0.192 & -1.51 & -0.267 & -1.48 \\
\hline $\mathrm{R}^{2}$ & 0.7875 & & 0.7333 & & 0.7400 & & 0.7969 & \\
\hline Adj R² & 0.7570 & & 0.6951 & & 0.7027 & & 0.7678 & \\
\hline$N$ & 838 & & 838 & & 838 & & 838 & \\
\hline F-stats & $25.83^{* * *}$ & & $19.17^{* * *}$ & & $19.84^{* * *}$ & & $27.35^{* * *}$ & \\
\hline \multicolumn{9}{|c|}{$\begin{array}{l}\text { Note: } Y_{i t} \text { is either market or book leverage. } B z e=\text { Bank's size, } M t b=\text { Market to book ratio, } R O A=\text { Return } \\
\text { on assets, } L r=\text { Loan ratio, } N p l=\text { Non-performing loans, } R w s=\text { Risk-weighted assets, } D D=\text { Distance to } \\
\text { Default, } P C V a R=\text { Conditional Value at Risk at } 95 \% \text { confidence level, } * * *, * * \text { and } * \text { denote significant at } \\
1 \%, 5 \% \text { and } 10 \% \text { levels, respectively. }\end{array}$} \\
\hline
\end{tabular}

The regression models estimate the all bank sample (including Thailand, Malaysia and Japan). The FE estimation, employing bank and time fixed effect is shown below

Table 7: Adding a one-year lag to the dependent variable

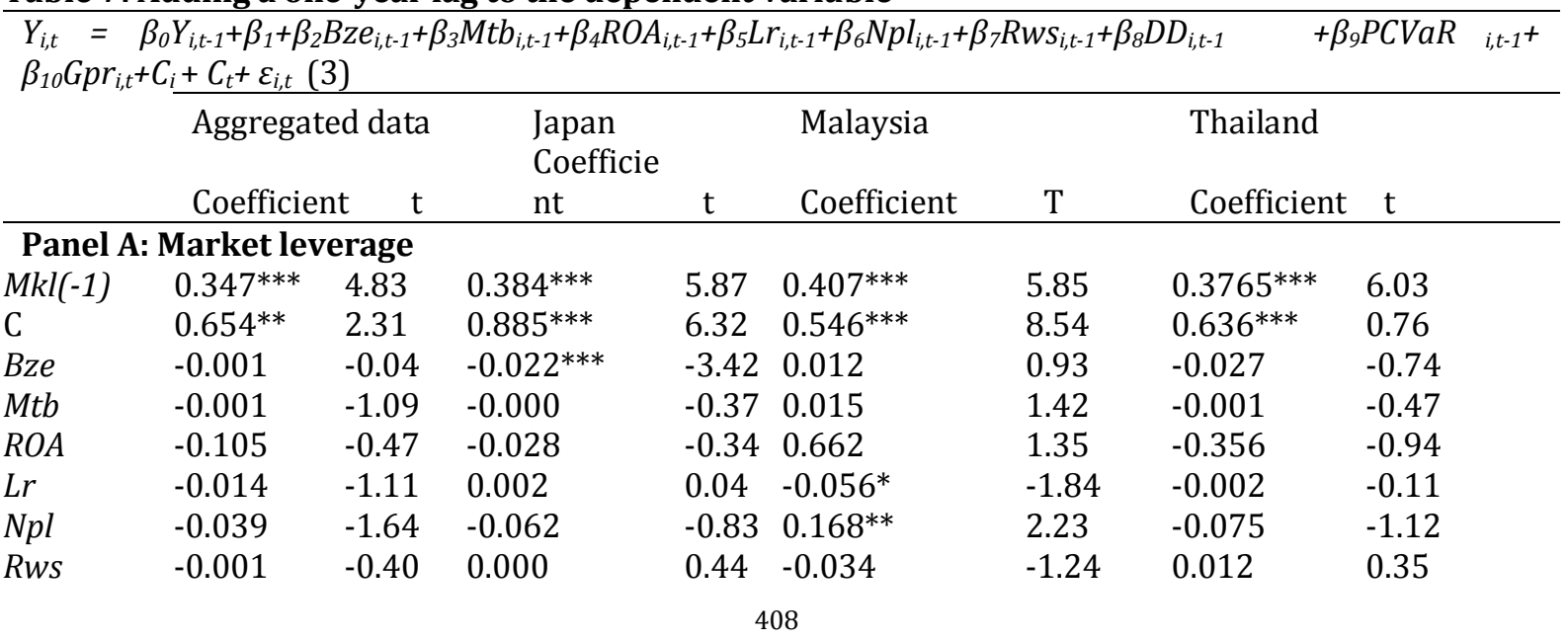




\begin{tabular}{|c|c|c|c|c|c|c|c|c|}
\hline$D D$ & -0.001 & -1.55 & -0.001 & -1.54 & -0.003 & -0.72 & 0.001 & 0.42 \\
\hline PCVaR & -0.004 & -1.49 & -0.002 & -1.49 & -0.007 & -0.55 & -0.006 & -0.65 \\
\hline$G p r$ & -0.168 & -0.53 & 0.372 & 0.75 & 0.118 & 0.454 & $-0.95^{* *}$ & -2.22 \\
\hline $\mathrm{R}^{2}$ & 0.8111 & & 0.8117 & & 0.8175 & & 0.8246 & \\
\hline Adj $R^{2}$ & 0.7837 & & 0.7844 & & 0.7911 & & 0.7991 & \\
\hline$N$ & 838 & & 838 & & 838 & & 838 & \\
\hline F-stats & $29.60^{* * *}$ & & $29.72^{* * *}$ & & $30.90^{* * *}$ & & $32.41^{* * *}$ & \\
\hline \multicolumn{9}{|c|}{ Panel B: Book leverage } \\
\hline$\overline{B k l(-1)}$ & $0.549^{* * *}$ & 4.47 & $0.604^{* * *}$ & 4.91 & $0.621^{* * *}$ & 4.22 & $0.519 * * *$ & 4.42 \\
\hline $\mathrm{C}$ & $0.445^{* * *}$ & 4.48 & $0.288^{* *}$ & 2.38 & $0.348^{* * *}$ & 2.64 & $0.473^{* * *}$ & 4.09 \\
\hline Bze & -0.001 & -0.35 & $0.008^{* *}$ & 2.19 & 0.005 & 0.66 & -0.014 & -1.42 \\
\hline$M t b$ & -0.000 & -0.25 & 0.000 & 1.16 & $-0.010^{* *}$ & -2.53 & -0.000 & -0.001 \\
\hline$R O A$ & -0.012 & -0.19 & -0.001 & -0.01 & -0.175 & -0.51 & 0.109 & 0.86 \\
\hline$L r$ & 0.004 & 0.62 & -0.025 & -1.56 & 0.008 & 0.40 & 0.008 & 0.81 \\
\hline$N p l$ & $0.093^{* * *}$ & 5.13 & 0.043 & 1.14 & $0.123^{* *}$ & 2.44 & $0.118^{* * *}$ & 3.55 \\
\hline$R w s$ & 0.001 & 0.85 & -0.001 & -1.27 & $0.021^{* *}$ & 2.41 & $0.037^{*}$ & 1.79 \\
\hline$D D$ & -0.000 & -0.68 & -0.000 & -0.41 & $0.003^{* * *}$ & 2.73 & -0.002 & -1.05 \\
\hline PCVaR & -0.002 & -1.52 & $-0.001^{* *}$ & -2.02 & 0.004 & 1.28 & -0.004 & -1.18 \\
\hline Gpr & -0.069 & -0.68 & -0.165 & -0.89 & $-0.125^{*}$ & -1.91 & -0.098 & -0.44 \\
\hline $\mathrm{R}^{2}$ & 0.8590 & & 0.8285 & & 0.8329 & & 0.8612 & \\
\hline Adj $R^{2}$ & 0.8385 & & 0.8036 & & 0.8087 & & 0.8410 & \\
\hline$N$ & 838 & & 838 & & 838 & & 838 & \\
\hline F-stats & $42.00^{* * *}$ & & $33.30 * * *$ & & $34.37^{* * *}$ & & $42.78^{* * *}$ & \\
\hline
\end{tabular}

Note: $Y_{i t}$ is either market or book leverage. Bze = Bank's size, $M t b=$ Market to book ratio, $R O A=$ Return on assets, $L r=$ Loan ratio, $N p l=$ Non-performing loans, $R w s=$ Risk-weighted assets, $D D=$ Distance to Default, PCVaR= Conditional Value at Risk at $95 \%$ confidence level, ${ }^{* * *},{ }^{* *}$ and ${ }^{*}$ denote significant at $1 \%, 5 \%$ and $10 \%$ levels, respectively.

$\mathrm{R}^{2}$ and adjusted $\mathrm{R}^{2}$ in each country significantly increase with the one-year lag applied to the explanatory variables. Importantly the one-year lag of both market and book leverage are significant at $1 \%$ in each country, reflecting the influence of the leverage from previous year.

\section{Conclusion}

The purpose of this study was to investigate the determinants of the capital structure of Thai banks by using panel data analysis. Two market-based risk variables: distance to default $(D D)$ and conditional value at risk $(P C V a R)$ are included to study the influence of market-based risk on leverage. DD and PCVaR contribute to a higher adjusted $\mathrm{R}^{2}$ for leverage types, especially market leverage. For Thai banks, nonperforming loans and risk-weighted assets are key factor on book leverage; while GDP growth is only a major factor for market leverage. For Japan, a developed country, the influence of $D D$ and PCVaR on both market and book leverage is strong after the AFC; while for Malaysia, a developing country, these factors effect only book leverage, which might reflect the impact of the Basel Accord capital adequacy regulations. No significant result exists for Thai banks. Additionally, after adding a one-year lag to the dependent variable, the results show a better fit for models for each country for $\mathrm{R}^{2}$ and adjusted $\mathrm{R}^{2}$. The results might include the effect of unobserved variables linked to bank regulations. This could be a topic for future research.

\section{References}

Ali, K., Akhtar, M. F. \& Sadaqat, S. (2011). Practical implication of capital structure theories: Empirical evidence from the commercial banks of Pakistan. European Journal of Social Sciences, 23(1), 165173.

Allen, D. E., Powell, R. J. \& Singh, A. K. (2011). Using quantile regression to estimate capital buffer requirements for Japanese banks. Edith Cowan University. Perth.

Bank Negara Malaysia. (2011). List of Licensed Banking Institutions in Malaysia Retrieved 11 November 2010, 2011, from http://www.bnm.gov.my/index.php?ch=13\&cat=banking\&type=CB\&fund=0\&cu $=0$

Bank of Thailand. (1997). Supervision report 1996-1997 Retrieved 3 March, 2009, fromhttp://www.bot.or.th/Thai/FinancialInstitutions/New_Publications/KeyDevFI/Supervision /Documents/SupervisionReport1997.pdf 
Beeson, M. \& Rosser, A. (1998). The East Asian economic crisis: a brief overview of the facts, theissues and the future. Working paper No.86. Asia Research Centre. Murdoch University. Perth, Western Australia.

Black, F. \& Scholes, M. (1973). The pricing of options and corporate liabilities. The Journal of Political Economy, 81(3), 637-654.

Blankenburg, S. \& Palma, J. G. (2009). Introduction: the global financial crisis. Cambridge Journal of Economics, 33, 531-538.

Caglayan, E. \& Sak, N. (2010). The determinants of capital structure: Evidence from the Turkish banks. Journal of Money, Investment and Banking, 15, 57-65.

Chan-Lau, J. A., Jobert, A. \& Kong, J. (2004). An Option-Based approach to bank vulnerabilities in Emerging Markets. Working paper 04/33. International Monetory Fund

Crosbie, P. \& Bohn, J. (2003). Modeling default risk: Modeling methodology. 1-31. Retrieved from http://www.ma.hw.ac.uk/ mcneil/F79CR/Crosbie_Bohn.pdf

Eviews 7. (2009). Eviews 7 User's guide. the United States of America: Quantitative Micro Software, LLC.

Gropp, R. \& Heider, F. (2010). The determinants of bank capital structure. Review of Finance, 14(4), 587622.

Gujarati, D. (2011). Econometrics by example. New york: Palgrave Macmillan.

Haas, R. D. \& Peeters, M. (2006). The dynamic adjustment towards target capital structure of firms in transition economics. Economics of Transition, 14(1), 133-169.

Harris, M. \& Raviv, A. (1991). The theory of capital structure. Journal of Finance, 46(1), 297-355.

Japanese Banker's Association. (2011). Principle financial institutions Retrieved 12 December, 2011, from http://www.zenginkyo.or.jp/en/banks/principal/index.html

Juca, M. N., Sousa, A. F. D. \& Fishlow, A. (2012). Capital structure determinant's of North American banks and the compensation executive program-An empirical study on the actual systemic crisis. International Journal of Business and Management, 7(17), 13-26.

Karunatilleka, E. (1999). The Asian economic crisis. (14). Retrieved from Economic policy and statistics section website:

Kawai, M. (2005). Reform of the Japanese banking system. Institute of Economic Research, Hitotisubashi University, Kunitachi, Tokyo.

Merton, R. C. (1974). On the pricing of corporate debt: The risk structure of interest rates. Journal of Finance, 2, 449 - 470.

Morgan, J. P. \& Reuters, K. (1996). RiskMetricsTM-Technical Document. Morgan Guaranty Trust Company of New York. New York. Retrieved from http://www.faculty.idc.ac.il/kobi/RiskMGT/rmtd.pdf

Octavia, M. \& Brown, R. (2010). Determinants of bank capital structure in developing countries: Regulatory capital requirement versus the standard determinants of capital structure. Journal of Emerging Markets, 15(1), 50-62.

Powell, R. (2007). Industry Value at Risk in Australia. Working paper, Edith Cowan University (ECU), Perth, Western Australia.

Rockafellar, R. T. \& Uryasev, S. (2000). Optimization of Conditional Value-at-Risk. [working paper]. Journal of Risk, 2(3), 21-41.

World Bank. (2011). GDP growth rate (annual\%) Retrieved 8 May, 2010, from http://data.worldbank.org/indicator/NY.GDP.MKTP.KD.ZG?page=4 